\title{
Piper gaudichaudianum Kunth: Seasonal Characterization of the Essential Oil Chemical Composition of Leaves and Reproductive Organs
}

\author{
Bianca Schindler ${ }^{1}$, Berta Maria Heinzmann ${ }^{2 *}$. \\ ${ }^{1}$ Universidade Federal de Santa Maria - Departamento de Ciências Florestais, Santa Maria, Rio Grande do Sul, \\ Brazil; ${ }^{2}$ Universidade Federal de Santa Maria - Departamento de Farmácia Industrial, Santa Maria, Rio Grande \\ do Sul, Brazil.
}

\begin{abstract}
This study describes a comparative analysis of the essential oil (EO) chemical composition of leaves and reproductive organs (inflorescences and fruits) of Piper gaudichaudianum during the seasons of a year in order to determine the best collection time and the most suitable plant organ to obtain this extractive. The chemical composition of EO obtained from fresh leaves was compared to the dried ones, to verify if the drying process interferes in the extractive quality. The leaves were collected from a native population of Santa Maria, RS, Brazil, twice in each season, in triplicate, while inflorescences and fruits were sampled when they were present. The EO was obtained by hydrodistillation of the different plant organs for $3 \mathrm{~h}$. The 20 EO samples were analyzed by gas chromatography $(G C)$ coupled to mass spectrometry and GC with flame ionization detector, in triplicate. Hierarchical cluster analysis (HCA) and principal components analysis (PCA) were performed to verify a possible formation of chemical groups (CG) and the cohesion among them. The phenylpropanoid dillapiole was the major constituent of the EO in all seasons and in all plant organs, and myristicin was observed only in reproductive organs. The EO samples of this population were divided into two CG by HCA and PCA, showing the variability in chemical composition between different plant organs, however there was no chemical variability due to seasonality and phenophases. Since the drying of the leaves did not alter the EO chemical composition, this post-harvest procedure can be used without compromising the extrative quality.
\end{abstract}

Key words: Pariparoba, plant extraction, medicinal plant, post-harvest processing.

\footnotetext{
*Author for correspondence: berta.heinzmann@gmail.com
} 


\section{INTRODUCTION}

Piperaceae species are quite common in Brazilian forests and have commercial, medicinal and ecological importance ${ }^{1}$.The genus Piper is classified in this family and it is know for its a wide variety of chemical constituents, among which monoterpenoids and sesquiterpenoids stand out ${ }^{2,3}$. Alcaloids, flavones, and phenylpropanoids as myristicin, asaricin, dillapiole and safrole also occur ${ }^{1,4,5}$.

Piper gaudichaudianum Kunth, known as pariparoba or jaborandi, is found in all Brazilian regions, and also in Paraguay and Argentina ${ }^{6,7}$. Regarding the bioactive secondary metabolites reported for this species, chromone and prenylated derivatives of benzoic acid isomers were obtained from the leaves ethanolic extract, which showed antimicrobial activity against strains of Staphylococcus aureus, Bacillus subtilis and Candida tropicalis ${ }^{8}$. Ethyl acetate extracts obtained from the leaves of $P$. gaudichaudianum in different developmental stages of the species showed changes in chemical composition as a result of metabolic alterations. In 12 months seedlings the major constituents were apiole and dilapiolle, but at 15 months gaudichaudianic acid was detected as main compound, which remained as major one in leaf extracts of adult plants ${ }^{9}$. In addition, the leaves essential oil (EO) having as its major component the sesquiterpene $\alpha$-humulene, followed by $\beta$-caryophyllene, viridiflorene, $\beta$-selinene, seychellene and $\delta$-cadinene ${ }^{10}$ showed antifungal activity against Candida neoformans and $C$. krusei. Additionally, for the EO from leaves having as its major constituent the viridiflorol and also aromadendrene, $\beta$-selinene and selin-1-en-4- $\alpha$-ol, larvicidal activity against Aedes aegypti $\mathrm{L}\left(\mathrm{IC}_{50}=121 \mu \mathrm{g} . \mathrm{mL}^{-1}\right)$ was described ${ }^{11}$.

Studies concerning a comparative analysis of the seasonality effect in the EO chemical composition of leaves and reproductive organs were not performed for Piper gaudichaudianum to date. There are also no studies about the evaluation of the possible influence of post-harvest processing on the EO quality of leaves. Therefore, the aim of this study was to perform a comparative analysis of the EO chemical composition of leaves and reproductive organs (inflorescences and fruits) of Piper gaudichaudianum Kunth considering the four seasons of a year, in order to determine the best collection time and the most suitable plant organ to obtain such extractive. Furthermore, chemical composition of the EOs obtained from fresh and dried leaves were compared, to verify whether the drying process interferes or not in extrative quality.

\section{MATERIAL AND METHODS}

\section{Plant material and collection site}

The leaves and reproductive organs were randomly collected from individuals in a native population of $P$. gaudichaudianum, located in the understory of a forest remnant in Santa Maria, state of Rio Grande do Sul, Brazil, under the coordinates S $29^{\circ} 40^{\prime} 11.3^{\prime \prime}$ and W 53 $46^{\prime} 15.8^{\prime \prime}$, and at altitude of around $229 \mathrm{~m}$. The samples were collected in the morning, between 8:30 and 9:30 am, two times in each season (spring, summer, autumn and winter), from January to December 2013. A total of eight collections were carried out. The species was identified by Daniele Ferreira Monteiro, and voucher specimens were deposited in the Herbarium of the Department of Forest Science (HDCF) at the Federal University of Santa Maria (UFSM) (Nr. 6,514) and a duplicate was sent to the Herbarium of Rio de Janeiro Botanical Garden (RB) (Nr. 584,729). The term used in plant morphology to the 
inflorescence of this species is cob, which characterizes sessile flowers (without pedicel $)^{12}$ and the fruit is called drupe ${ }^{6}$.

The vegetation in Santa Maria is classified as Seasonal Deciduous Forest ${ }^{13}$. In order to characterize the collection site, the new proposal made by Oliveira-Filho ${ }^{14}$ was chosen. According to this proposal, the forestry formation is classified as Broadleaved Forest Seasonal Rocky. According to Heldwein et al. ${ }^{15}$ the climate of this region is classified as mesothermal and humid from Cfa type, characterized as humid subtropical with hot summers without a defined dry season. The average annual temperature is $19.1{ }^{\circ} \mathrm{C}$ and monthly rainfall lies between $120.1 \mathrm{~mm}$ and 126.8 $\mathrm{mm}$. The region is subjected to low and moderate frost, with mild winter, but subject to cold waves caused by the frequent displacement of migratory polar anticyclones. Meteorological data were obtained from the INMET (National Institute of Meteorology) to characterize the year of study (Table 1). The soil of Santa Maria sits on lithology of the formations Santa Maria, Caturrita, Botucatu and Serra Geral ${ }^{16}$. The collection site has soil type Litholic Neosol ${ }^{17}$.

Table 1- Meteorological data from 2013 for Santa Maria, RS, Brazil.

\begin{tabular}{|c|c|c|c|c|c|c|c|c|c|c|c|c|}
\hline \multirow{3}{*}{$\begin{array}{l}\text { Monthly } \\
\text { average }\end{array}$} & \multicolumn{12}{|c|}{ Seasons and months } \\
\hline & \multicolumn{3}{|c|}{ Summer } & \multicolumn{3}{|c|}{ Autumn } & \multicolumn{3}{|c|}{ Winter } & \multicolumn{3}{|l|}{ Spring } \\
\hline & $\mathbf{J}$ & $\mathbf{F}$ & $\mathbf{M}$ & A & $\mathbf{M}$ & $\mathbf{J}$ & $\mathbf{J}$ & $\mathbf{A}$ & $\mathbf{S}$ & $\mathbf{O}$ & $\mathbf{N}$ & D \\
\hline $\begin{array}{l}\text { Min. } \\
\text { temp. }\left({ }^{\circ} \mathbf{C}\right)\end{array}$ & 18.2 & 19.1 & 16.4 & 14.4 & 11.0 & 9.5 & 8.7 & 8.1 & 12.7 & 14.2 & 17.5 & 19.7 \\
\hline $\begin{array}{l}\text { Max. } \\
\text { temp. }\left({ }^{\circ} \mathbf{C}\right)\end{array}$ & 30.3 & 29.9 & 26.6 & 26.4 & 21.4 & 18.9 & 20.0 & 19.3 & 23.1 & 26.2 & 28.7 & 32.1 \\
\hline $\begin{array}{l}\text { Precip. } \\
\text { (mm) }\end{array}$ & 145.3 & 97.7 & 188.6 & 147.4 & 71.6 & 81.6 & 113.5 & 163.8 & 69.2 & 108.7 & 294.5 & 92.8 \\
\hline RH (\%) & 75.8 & 80.9 & 83.8 & 83.5 & 87.2 & 89.7 & 86.8 & 83.1 & 78.0 & 74.0 & 72.7 & 70.1 \\
\hline
\end{tabular}

Subtitles: Min. Temp. $\left({ }^{\circ} \mathrm{C}\right)$ : Minimum temperature; Max. temp. $\left({ }^{\circ} \mathrm{C}\right)$ : Maximum temperature; Precip. (mm): Precipitation; RH (\%): Relative humidity.

\section{Essential oil extraction and chemical composition analysis}

The EOs were obtained from fresh leaves and reproductive organs as well as from dried leaves, which were dried for 15 days at room temperature and away from light. Plant material was fragmented and separately submitted to hydrodistillation for the extraction of the EOs of different plant organs, using a modified Clevenger type apparatus for 3 hours. In this method, the distillate oil is retained in a graduated glass tube, and the aqueous phase returns automatically to the distillation flask to be reused ${ }^{18}$. The extraction from fresh and dried leaves was performed in triplicate, while the reproductive organs were extracted only once in each collection, due to the small amount of material available. As the EO mixed with hidrolate, this was subjected to liquid-liquid extraction in a separator funnel using previously distilled hexane ${ }^{19}$. After drying through the hexane fraction with anhydrous sodium sulfate $\left(\mathrm{Na}_{2} \mathrm{SO}_{4}\right)$, the solvent was evaporated under reduced pressure at $30{ }^{\circ} \mathrm{C}$ to obtain the EOs. These EOs were stored in sealed amber glass bottles, at $4{ }^{\circ} \mathrm{C}$. For chemical composition analysis samples were prepared by diluting the EO in hexane HPLC grade at $2 \%$.

The 20 EO samples obtained from plant material of all the collections are represented by abbreviations, which were made according the seasons (Su: summer, Au: autumn, Wi: winter and Sp: spring), the plant organ (FL: fresh leaves; DL: dried leaves; INF: inflorescences and F: fruits), and the collection in the same season (1 or 2). Thus, the essential oil samples were named: SuFL1, SuFL2, SuDL1, SuDL2, 
AuFl1, AuFl2, AuDL1, AuDL2, AuINF2, WiFL1, WiFL2, WiDL1, WiDL2, WiINF2, SpFL1, SpF1, SpDL1, SpFL2, SpDL2 and SpF2.

The EOs chemical analyses were carried out by gas chromatography coupled to mass spectrometry (GC-MS) on a hyphenated Agilent 7890A System equipped with a mass selective detector 5975C. The analysis parameters were: split mode (1: 100 $\mathrm{v} / \mathrm{v}$ ); carrier gas: He (flow of $1 \mathrm{~mL} / \mathrm{min}$ ); Capillary column HP-5MS (Hewlett Packard, 5\% phenylmethylsiloxane, $30 \mathrm{~m}$ x $0.25 \mathrm{~mm}$, film thickness: $0.25 \mu \mathrm{m}$ ); oven temperature program: $40{ }^{\circ} \mathrm{C}$ (Ti) for $4 \mathrm{~min}, 40-320{ }^{\circ} \mathrm{C}$, at $4{ }^{\circ} \mathrm{C} / \mathrm{min}$; injector temperature: $250{ }^{\circ} \mathrm{C}$; interface temperature: $250{ }^{\circ} \mathrm{C}$; Ionization energy: $70 \mathrm{eV}$. The EOs components were identified based on the comparison of their retention index (RI) determined through a calibration curve of a n-alkanes homologous series (C8C32) injected under the same chromatographic conditions of the samples and based on the mass spectra obtained from the literature ${ }^{20,21}$.

The EOs constituents were quantified by a gas chromatography Agilent 7890A system with a flame ionization detector (GC-FID) in triplicate. The analysis parameters were equivalent to the ones previously mentioned, except for splitless mode; injector and detector temperature: $300{ }^{\circ} \mathrm{C}$.

\section{Multivariate analysis}

To investigate the possible seasonal variability in the chemical composition of the EOs and any differences arising from the extracted plant organ, as well as the drying process, multivariate techniques were used. Furthermore, the Hierarchical Cluster Analysis (HCA) with the Euclidean distance as a measure of dissimilarity and the average linkage $\mathrm{UPGMA}^{22}$ to obtain the cophenetic correlation coefficient (CCC) which indicates the adequacy of the grouping formed by the proximity of 1.0 were chosen $^{23}$. The Principal Component Analysis (PCA) was also performed to determine which variables (constituents) affected the formation of chemical groups of $\mathrm{EOs}^{24}$. The data matrix analysis was composed by 20 samples (objects) and nine EO constituents (descriptors) at concentrations $>3.0 \%$ in at least one sample. Both analyses were performed using the statistical program $\mathrm{R}$ version 2.15.2, and packages "vegan"25 and "stats"26.

\section{RESULTS AND DISCUSSION}

In the $20 \mathrm{EO}$ samples obtained during the studied period, 24 components were identified and quantified, comprising 92.8 to $100 \%$ of their total chemical composition (Table 2). The phenylpropanoid dillapiole was the predominant constituent of the EO samples obtained from different plant organs in all seasons of the year, while myristicin was observed only in reproductive organs (6.2 to $11.9 \%)$ (Fig. 1). Considering the fresh leaves, they have the highest percentage of dillapiole (68.4 to $69.2 \%$ ) when collected in winter and summer. Comparing the extracted plant organs, the inflorescences under development (in the winter) and fruits (in the spring) had the highest proportions of this constituent, with 87.5 to $87.8 \%$, while during the flowering initial period (in the autumn) and final fruit ripening (in the spring) the levels of dillapiole found were 83.1 and $85.2 \%$, respectively.

The sesquiterpene hydrocarbons comprised 22.5 to $36.4 \%$ from the total of the EO samples, and oxygenated hydrocarbons amounted 0.2 to $5.8 \%$, where the latter class was only in one of the EO samples obtained from inflorescences (autumn) with 0.2 $\%$. The monoterpene hydrocarbons were identified in trace amounts only in the EO resulting from the first collection of fruits (spring) in a total of $0.3 \%$. It is noteworthy that the oxygenated monoterpenoids were not identified in any of the EO samples of this population. 

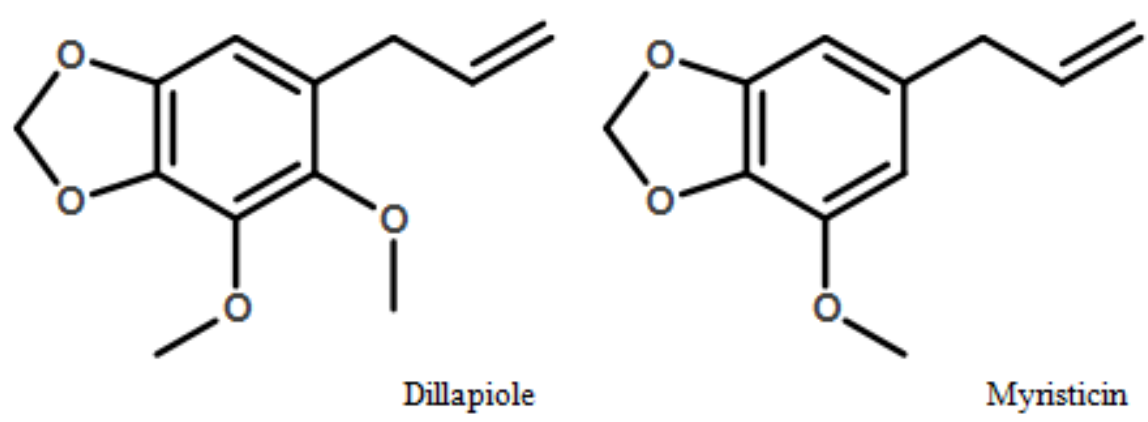

Figure 1 - Chemical structure of dominant constituents of Piper gaudichaudianum essential oils obtained from leaves and reproductive organs.

Among the major sesquiterpenoids, $\alpha$-humulene, $\beta$-caryophyllene, iswarane, germacrene $\mathrm{B}, \delta$-cadinene and $E$-nerolidol stand out. The components $\alpha$-copaene, $\beta$ bourbonene and humulene epoxide II were observed in EO samples of fresh and dried leaves collected during summer and autumn, although in small proportions. Moreover, $\beta$-copaene, $\alpha$-bulnesene, $\tau$ - and $\delta$-cadinol were detected only in fresh and dried leaves obtained during summer (Table 2).

The EOs from fresh and dried leaves (Fig. 2) and reproductive organs presented a different chemical profile from those found in literature for this species, due to the strong presence of the phenylpropanoid class. Accordingly, a low concentration and diversity of other classes of volatile constituents previously described for $P$. gaudichaudianum was observed ${ }^{27,28 ; 29,30}$. In the group of the major constituents verified for EOs of leaves and inflorescences of $P$. gaudichaudianum growing in some cities of Rio Grande do Sul state, $\alpha$-humulene (13.3-37.5\%), B-caryophyllene (10.4-19.3\%), B-pinene (5.6-7\%), $E$-nerolidol (5.32-22.4\%), $E$-caryophyllene $(8.9 \%)$, bicyclogermacrene (7.4\%), $\beta$-selinene (3.7-15.7\%), $\alpha$-selinene (8.9-16.6\%), allo-aromadendrene $(7.7 \%)$ and linalool $(4.8 \%)$ are the most frequently cited ${ }^{27,28,29}$. However, in a seasonal study in the city of Atalanta (SC), $\beta$-caryophyllene (10.4$12.5 \%), \alpha$-humulene $(8.2-10.4 \%), \delta$-selinene $(5.4-6.9 \%), \delta$-cadinene $(6.0-7.3 \%) ; E$ nerolidol (3.0-7.2\%) Z- $\beta$-guaiene (5.5-5.6\%), and valencene $(4.0-5.6 \%)$ were observed $^{30}$. The EO chemical composition of $P$. gaudichaudianum leaves found in this study is similar to those described for the EO of leaves obtained from Piper permucronatum Yunck. collected in Rondônia and Piper aduncum L. in Pará and Distrito Federal. The dillapiole levels observed in these EOs ranged from 54.7\% and 31.5-97.3\%, respectively ${ }^{31,11,32,33}$.

口Sesquiterpenes \$Phenylpropanoids

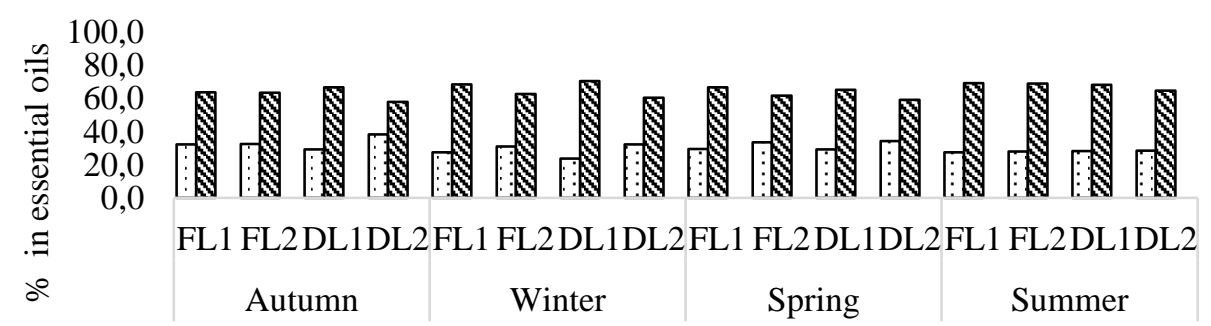

Figure 2 - Chemical classes detected in the essential oils from leaves (fresh and dried) of Piper gaudichaudianum Kunth in the four seasons (Autumn, Winter, Spring, Summer) in 2013.

Subtitle - plant organ (FL: fresh leaves; DL: dried leaves); collection in the same season (1 or 2). 


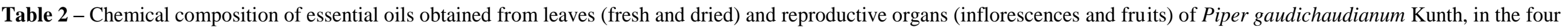

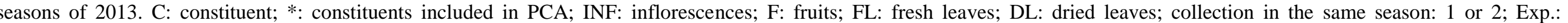
experimental; Lit.: literature.

\begin{tabular}{|c|c|c|c|c|c|c|c|c|c|c|c|c|c|c|c|c|c|c|c|c|c|c|c|}
\hline \multirow{3}{*}{\multicolumn{2}{|c|}{ Constituents }} & \multirow{2}{*}{\multicolumn{2}{|c|}{$\begin{array}{l}\text { Kovats } \\
\text { Index }\end{array}$}} & \multicolumn{20}{|c|}{ Percentage \% } \\
\hline & & & & \multicolumn{5}{|c|}{ Autumn } & \multicolumn{5}{|c|}{ Winter } & \multicolumn{6}{|c|}{ Spring } & \multicolumn{4}{|c|}{ Summer } \\
\hline & & Exp. & Liter & INF2 & FL1 & FL2 & DL1 & DL2 & INF2 & FL1 & FL2 & DL1 & DL2 & $\mathrm{F} 1$ & $\mathrm{~F} 2$ & FL1 & FL2 & DL1 & DL2 & FL1 & FL2 & DL1 & DL2 \\
\hline $\mathrm{C} 1$ & $\alpha$-Pinene & 932 & 939 & - & - & - & - & - & - & - & - & - & - & 0.1 & - & - & - & - & - & - & - & - & - \\
\hline $\mathrm{C} 2$ & Sabinene & 974 & 972 & - & - & - & - & - & - & - & - & - & - & 0.2 & - & - & - & - & - & - & - & - & - \\
\hline $\mathrm{C} 3$ & $\alpha$-Copaene & 1376 & 1375 & - & 0.4 & 0.4 & - & 0.5 & - & - & - & - & - & - & - & - & - & - & - & 0.3 & 0.3 & 0.3 & 0.4 \\
\hline $\mathrm{C} 4$ & $\beta$-Bourbonene & 1385 & 1384 & - & 0.5 & 0.4 & - & 0.5 & - & - & - & 0.5 & - & - & - & - & - & - & - & 0.3 & 0.4 & 0.3 & 0.4 \\
\hline *C5 & $\beta$-Caryophyllene & 1420 & 1420 & 1.2 & 3.7 & 4.2 & 4.0 & 5.0 & - & 3.5 & 3.8 & 3.8 & 4.6 & - & 0.7 & 3.9 & 4.2 & 3.8 & 4.9 & 4.0 & 3.1 & 3.7 & 4.3 \\
\hline C6 & $\beta$-Copaene & 1424 & 1432 & - & 0.6 & - & - & - & - & - & - & - & - & - & - & - & - & - & - & 0.4 & 0.4 & 0.4 & - \\
\hline$* \mathrm{C} 7$ & Aromadendrene & 1439 & 1439 & - & 0.4 & 2.5 & 2.4 & 3.5 & - & 2.6 & - & 2.4 & 1.6 & - & - & - & 2.0 & 1.5 & - & 0.2 & 1.7 & 2.0 & 2.1 \\
\hline$* \mathrm{C} 8$ & $\alpha$-Humulene & 1455 & 1454 & 2.7 & 11.8 & 13.3 & 12.0 & 14.3 & 1.4 & 10.2 & 8.2 & 7.9 & 10.1 & - & 1.4 & 9.7 & 9.3 & 9.3 & 11.2 & 9.6 & 8.4 & 10.2 & 10.9 \\
\hline$* \mathrm{C} 9$ & Ishwarene & 1463 & 1466 & 0.4 & 3.9 & 4.3 & 3.3 & 1.4 & - & 2.5 & 4.1 & 2.8 & 3.7 & - & 0.7 & 5.0 & 4.2 & 3.8 & 6.4 & 1.3 & 3.7 & 1.9 & 1.9 \\
\hline $\mathrm{C} 10$ & Germacrene D & 1482 & 1482 & - & 2.1 & - & - & - & - & - & - & - & - & - & 2.3 & - & - & - & - & - & - & - & - \\
\hline $\mathrm{C} 11$ & $\alpha$-Bulnesene & 1487 & 1489 & - & - & - & - & 1.6 & - & - & - & - & - & - & - & - & - & - & - & 1.9 & 1.1 & 1.6 & - \\
\hline C12 & $\alpha$-Selinene & 1487 & 1485 & - & - & - & - & - & - & - & - & - & - & - & - & - & 1.3 & - & 1.5 & - & - & - & - \\
\hline$* \mathrm{C} 13$ & Germacrene B & 1498 & 1500 & 2.5 & 6.9 & 4.7 & 5.8 & 5.9 & 1.8 & 6.1 & 6.9 & 5.0 & 7.4 & - & 2.0 & 5.1 & 6.1 & 5.9 & 5.4 & 4.4 & 4.4 & 1.2 & 4.2 \\
\hline${ }^{*} \mathrm{C} 14$ & $\delta$-Cadinene & 1508 & 1505 & - & 0.5 & 1.3 & 1.6 & 3.7 & - & - & 2.7 & - & 2.3 & - & - & - & 2.8 & - & 1.9 & 1.7 & 1.3 & 4.0 & 1.5 \\
\hline$* \mathrm{C} 15$ & Myristicin & 1523 & 1523 & 6.2 & - & - & - & - & 9.3 & - & - & - & - & 11.9 & 6.9 & - & - & - & - & - & - & - & - \\
\hline $\mathrm{C} 16$ & Elemicin & 1559 & 1558 & - & - & - & - & - & - & - & - & - & - & - & 1.0 & - & - & - & - & - & - & - & - \\
\hline$* \mathrm{C} 17$ & $E$-Nerolidol & 1565 & 1564 & - & 0.9 & 0.9 & - & 1.1 & - & - & 3.0 & - & - & - & - & - & - & 3.0 & 2.9 & 0.2 & 1.2 & 1.3 & 1.5 \\
\hline $\mathrm{C} 18$ & Spathulenol & 1579 & 1576 & - & 0.2 & 0.2 & - & 0.2 & - & 0.9 & 2.1 & 0.2 & 1.8 & - & - & 2.1 & 1.2 & 1.9 & - & 1.6 & - & 0.2 & 1.4 \\
\hline C19 & Caryophyllene oxide & 1585 & 1583 & - & - & - & - & 0.3 & - & - & - & - & - & - & - & - & - & - & - & - & - & - & - \\
\hline $\mathrm{C} 20$ & Epoxy Humulene II & 1611 & 1608 & - & 0.6 & 0.4 & - & - & - & - & - & - & - & - & - & - & - & - & - & 0.6 & 0.7 & 0.5 & - \\
\hline$* \mathrm{C} 21$ & Dillapiole & 1626 & 1620 & 83.1 & 63.6 & 63.4 & 66.7 & 57.8 & 87.5 & 68.4 & 62.7 & 70.5 & 60.5 & 87.8 & 85.2 & 66.6 & 61.6 & 65.2 & 59.2 & 69.2 & 68.8 & 68.1 & 64.7 \\
\hline $\mathrm{C} 22$ & $\delta$-Cadinol & 1643 & 1636 & - & - & - & - & - & - & - & - & - & - & - & - & - & - & - & - & 0.8 & 0.5 & 0.4 & - \\
\hline $\mathrm{C} 23$ & $\tau$-Cadinol & 1643 & 1648 & - & - & - & - & 0.2 & - & - & - & - & - & - & - & - & - & - & - & 0.3 & 0.6 & 0.2 & - \\
\hline $\mathrm{C} 24$ & $\tau$-Muurolol & 1657 & 1661 & 0.2 & - & - & - & - & - & - & - & - & 0.8 & - & - & - & - & - & - & - & - & - & - \\
\hline \multicolumn{2}{|c|}{ Total identified } & & & 96.4 & 96.0 & 96.0 & 95.8 & 96.1 & 100 & 95.8 & 93.6 & 94.1 & 92.8 & 100 & 100 & 96.2 & 95.0 & 94.4 & 93.3 & 96.7 & 96.7 & 96.3 & 93.3 \\
\hline
\end{tabular}

Braz. Arch. Biol. Technol. v.60: e17160441 Jan/Dec 2017 
This difference in chemical composition of the EOs of the studied population compared to the other works carried out with the same $P$. gaudichaudianum extractive may occur due to environmental, genetic and biotic factors. The chemical variability may result from environmental and/ or ecological selection pressure, featuring a chemical adjustment to prevailing environmental conditions ${ }^{34}$. In a study with the EOs from leaves of Myrciaria cauliflora (Mart.) O. Berg. variability in the chemical composition could also be observed ${ }^{35}$. Furthermore, chemical variations of EOs by genetic influence may occur together with environmental factors, as reported to Eugenia dysenterica DC. ${ }^{36}$. According to these studies, evolutionary pressure resulted in selection of a specialized phenotype, also called ecotype, which is more effective and better adapted to local environmental conditions. This was also observed for some individuals of Thymus pulegoides L., for which the stability of the EOs chemical composition was associated with their genetically predetermined characteristics ${ }^{37}$. Additionally, phenylpropanoids are often considered chemical responses to local abiotic and biotic stress as the attack of pathogens, mechanical damage, low temperatures, and nutritional deficiencies, among others ${ }^{38}$. Thus, the amount of dillapiole in the EOs of leaves and reproductive organs suggests a defense function for this constituent. The concentrations of safrole, another phenylpropanoid and major component in Piper mikanianum (Kunth) Steudel leaves EO, were elevated in all seasons ${ }^{39}$. However, in undamaged leaves, its percentage was slightly lower than in damaged leaves (72 and $76 \%$ respectively). The possible defense function for dillapiole is supported by the biological activities described for Piper aduncum L. leaves EOs, as antifungal and insecticide ${ }^{40,41,42}$. The EO of this species has also dillapiole as the major component ${ }^{31}$. Moreover, dillapiol isolated from Piper holtonii C. DC. also showed antifungal activity ${ }^{43}$. In addition, a study of the chemical composition of extracts obtained from leaves of Piper gaudichaudianum at different stages of development, detected the presence of apiole and dilapiolle as major components in 12 month seedlings. The fact that these components have been replaced by acid gaudichaudianic in leaves of adult plants, led the authors to the conclusion that the apiol and dillapiole have protective function of the seedlings against biotic factors?

The differences in the chemical composition of the EO analyzed samples (FL, DL, INF, FR) were particularly observed in the results of Hierarchical Cluster Analysis (HCA) and Principal Component Analysis (PCA) (Fig. 3 and 4, respectively). The analysis showed a clear separation of the EOs extracted from different plant organs in different chemical groups (CG), as can be observed for the reproductive organs (CG I) and fresh and dried leaves (CG II). CG I is formed by samples of inflorescences EOs collected in winter and autumn, as well as fruits harvested in spring. CG II consists of all leaf samples, regardless of the collection season and state (fresh or dried). The HCA cophenetic correlation was 0.95 , indicating that the degree of grouping setting is appropriate. The location of the storage structures for the EOs inside the leaves tissues in Piper species is a probable explanation for the fact that the drying process did not significantly alter their chemical composition ${ }^{44}$. This can be evidenced in the HCA, since the EOs of dried and fresh leaves were classified in the same CG (Fig. 3). 


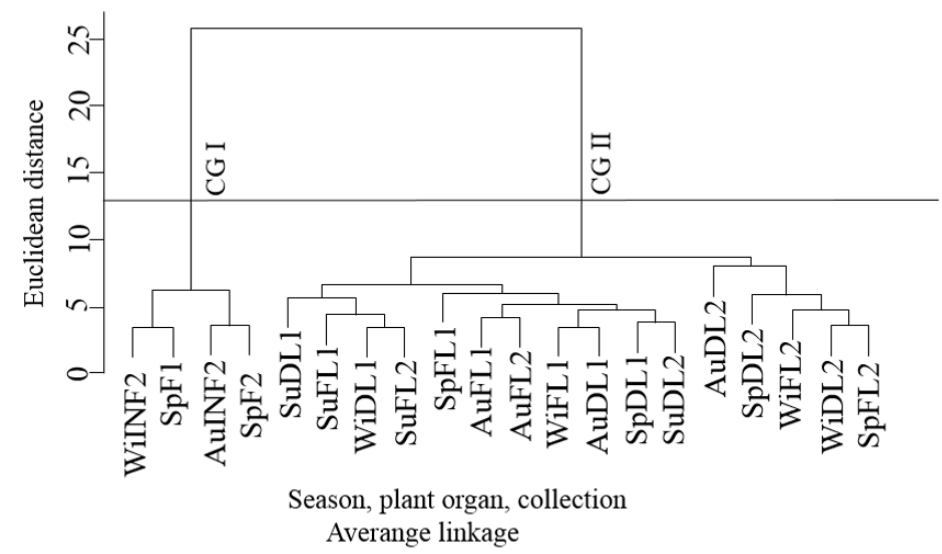

Figure 3 - Dendrogram with Hierarchical Cluster Analysis of the chemical composition of all essential oil samples of Piper gaudichaudianum Kunth, obtained from different plant organs in the four seasons of 2013, by the average linkage and the Euclidean distance as a measure of dissimilarity, showing the division into two chemical groups (CG I and II).

Subtitle - Abbreviations order: season (Wi: Winter; Sp: Spring; Au: Autumn; Su: Summer), plant organ (INF: inflorescences; F: fruits; DL: dried leaves; FL: fresh leaves), collection in the same season (1 or 2).

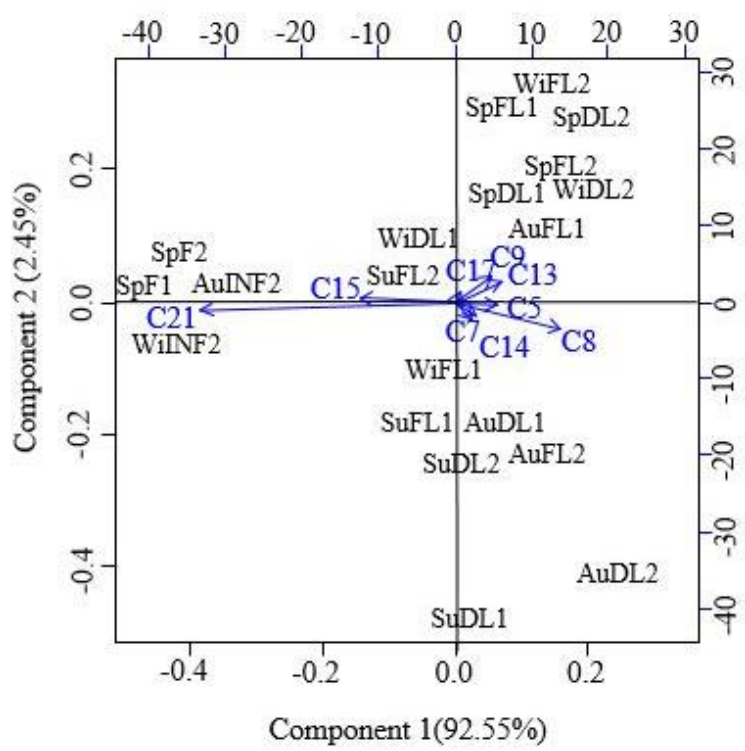

Figure 4 - Biplot of Principal Component Analysis (PCA), based on the chemical composition of 20 essential oils samples, obtained from leaves (fresh and dried) and reproductive organs (inflorescences and fruits) of Piper gaudichaudianum Kunth in the four seasons in 2013.

Subtitles- Abbreviations Order: Objects - season (Au: Autumn, Wi: Winter, Sp: Spring, Su: Summer), plant organ (INF: inflorescences; F: fruits; DL: dried leaves; FL: fresh leaves), collection (1 or 2); Descriptors - constituents: C5: $\beta$-caryophyllene; C7: aromadendrene; C8: $\alpha$-humulene; C9: ishwarene; C13: germacrene B; C14: $\delta$-cadinene; C15: myristicin, C17: E-nerolidol and C21: dillapiole).

The PCA generated nine principal components (PC), and out of these, two explain $95 \%$ of the accumulated variation of the EOs chemical composition data of fresh and dried leaves, and also of reproductive organs (data not shown). The results of the multivariate techniques used in this work are in agreement with each other, since the number of representative principal components in the PCA (Fig. 4) is similar to the number of chemical groups formed in HCA (Fig. 3). The results obtained from the HCA and PCA indicate chemical variability of EOs among $P$. gaudichaudianum studied organs. However, this variation is small when comparing the EOs of fresh 
and dried leaves and between both reproductive organs analyzed (inflorescences and fruits), since the PC 2 is $2.45 \%$.

According to the PCA (Fig. 4), myristicin and dillapiole are related to EO samples of reproductive organs. Although dillapiole is the major component in all EO samples of this study, it is not directed to the EO samples of fresh and dried leaves, possibly because the reproductive organs presented low diversity of constituents in their composition. Thus, the chemical composition of EOs from fresh and dried leaves form the CG with greater number and variability of constituents.

In this study, the chemical groups formed by multivariate analysis HCA and PCA were independent from the collection period and phenophases, indicating absence of seasonal variability in the EO chemical composition from leaves (fresh and dried) and reproductive organs (inflorescences and fruits) of $P$. gaudichaudianum. This EOs chemical composition stability throughout the seasons of the year was also reported to Lantana camara L. in Madagascar, where the seasons are very distinct and extreme ${ }^{45}$. To Myrcia obtecta (O. Berg) Kiaersk. var. obtecta the variability in the EOs composition of leaves due to seasonality was also not observed, but it occurred due to physiology/ plant phenology, since a different chemical composition was detected in the flowering period ${ }^{46}$. Differences among the EOs composition of the leaves and reproductive organs are expected, since the aroma emitted by the inflorescences are associated to the attraction of specific pollinators, still acting to protect the reproductive organs against possible enemies ${ }^{47,48}$. The fruit bats as Carollia perspicillata that feed from the fruits of various Piper species, use the smell as the main sense for the location of ripe fruits ${ }^{49}$. These previous studies indicate a possible explanation for the detection of myristicin, which has spicy and musky odor, only in the reproductive organs, suggesting the role of attracting pollinators and dispersers. In this respect, the fact that this substance showed a higher concentration in the seasons where the inflorescences were in transition to fruiting (9.3 to $11.9 \%$ ) is also noteworthy. The metabolic pathways and the genes, which regulate the synthesis of enzymes for the biosynthesis of odoriferous constituents, are primarily those that produce volatile terpenoids, phenylpropanoids, or volatile fatty acid derivatives ${ }^{48}$.

The EO chemical composition is genetically determined and can be altered by many factors, which may be related to the physiology of the plant, reproductive or vegetative cycle, defense or pollinators attraction, extraction method and sampling technique, environmental pollution, among others ${ }^{50,51,52}$. Researches about the genetic aspects of different populations of $P$. gaudichaudianum should be performed considering ecology and phenology as well as comparing different collection times of plant material for extraction. Such works would determine the unchangeability in the EOs chemical composition as it happened with this population during the months of the observed year.

\section{CONCLUSION}

The investigation of the EOs chemical variability of Piper gaudichaudianum revealed a constant composition regarding the seasons for the year and population sampled, and only little variability between the EOs obtained from different plant organs. Thus, the plant material can be collected in any period of the year. Dillapiole, an interesting constituent because of its already reported biological activities, was detected in these extractives as major component. The chemical composition of the EOs from leaves remains unchanged during drying. This way, 
this plant organ can be subjected to such post-harvest processing prior to extraction because it did not compromise the quality of the extractive.

\section{REFERENCES}

1- Parmar VS et al. Phytochemistry of genus Piper. Phytochemistry. 1997; 46(4):597-673.

2- Cysne JB, Canuto KM, Pessoa ODL, Nunes EP, Silveira ER. Leaf essential oils of four Piper species from the state of Ceará - Northeast of Brazil. Journal of the Brazilian Chemical Society. 2005; 16(6B):1378-1381.

3- Mesquita JMO, Cavaleiro C, Cunha, AP, Lombardi JA, Oliveira AB. Estudo comparativo dos óleos voláteis de algumas espécies de Piperaceae. Revista Brasileira de Farmacognosia, 2005; 15(1):6-12.

4- Santos, PRD, Moreira DL, Guimarães EF, Kaplan MAC. Essential oil of 10 Piperaceae species from the Brazilian atlantic forest. Phytochemistry, 2001; 58(4): 547-551.

5- Abreu AM, Sevegnani L, Machicado AR, Zimermann D, Rebelo RA. Piper mikanianum (Kunth) Steudel from Santa Catarina, Brazil - a New Source of Safrole. Journal Essential Oil Research. 2002, 14:361-363.

6- Guimarães EF, Valente, MC. Piperáceas - Piper. Flora Ilustrada Catarinense. Itajaí, Santa Catarina. 2001, p. 104.

7- Guimarães EF, Carvalho-Silva M, Monteiro D, Medeiros ES. Piperaceae in Lista de Espécies da Flora do Brasil. Jardim Botânico do Rio de Janeiro. [Internet]. 2014 [cited 2014 May 18] Avaible from: http://floradobrasil.jbrj.gov.br/2012/FB012738.

8- Puhl MCMN, Cortez DAG, Ueda-Nakamura T, Nakamura CV, Dias-Filho BP. Antimicrobial Activity of Piper gaudichaudianum Kuntze and Its Synergism with Different Antibiotics. Molecules. 2011, 16:9925-9938.

9- Gaia AM, Yamaguchi LF, Jeffrey CS, Kato MJ. Age-dependent changes from allylphenol to prenylated benzoic acid production in Piper gaudichaudianum Kunth. Phytochemistry. 2014, 106:86-93.

10-Morandim-Giannetti AA et al. Composition and antifungal activity against Candida albicans, Candida parapsilosis, Candida krusei and Cryptococcus neoformans of essential oils from leaves of Piper and Peperomia species. Journal of Medicinal Plants Research. 2010; 4(17):1810-1814.

11-Morais SM et al. Chemical composition and larvicidal activity of essential oils from Piper species. Biochemical Systematics and Ecology. 2007; 35:670-675.

12-Gonçalves EG, Lorenzi H. Morfologia vegetal - organografia e dicionário ilustrado de morfologia das plantas vasculares. 2nd ed. São Paulo: Instituto Plantarum de Estudos da Flora; 2011. p. 512.

13-IBGE. Manual técnico da vegetação brasileira. 2nd ed. Rio de Janeiro: IBGE; 2012.

14-Oliveira-Filho AT. Classificação das Fitofisionomias da América do Sul-Cisandina Tropical e Subtropical: proposta de um novo sistema - prático e flexível - ou uma injeção a mais de caos? Rodriguésia. 2009; 2(60):237-258.

15-Heldwein AB, Buriol GA, Streck NA. O clima de Santa Maria. Ciência \& Ambiente. 2009; 38:43-58.

16-Maciel Filho, CL. Carta Geotécnica de Santa Maria. Santa Maria: Imprensa Universitária. 1990. p. 24.

17-Streck, E. V. et al. Solos do Rio Grande do Sul. 2nd ed. Porto Alegre: EMATER - RS ASCAR. p. 86-88, 2008. 222p.

18-Sartor RB. Modelagem, simulação e otimização de unidade industrial de extração de óleos essenciais por arraste a vapor. [Dissertação em Engenharia Química]. Porto Alegre, Brasil: Universidade Federal do Rio Grande do Sul; 2009.

19-Silva RS, Ribeiro CMR, Borges MN, Blois GSO. Óleo essencial de limão no ensino da cromatografia em camada delgada. Química Nova. 2009; 32(8):2234-2237.

20-Adams RP. Identification of essential oil components by gas chromatography quadrupole mass spectrometry. Carol Stream: Allured Publishing Corporation, 2009.

21-National Institute of Standards and Technology, NIST. NIST/EPA/NIH mass spectral library \& search/analysis programs NIST 02 update. Hoboken, USA: John Wiley \& Sons; 2010. 
22-Valentin JL. Ecologia numérica: uma introdução à análise multivariada de dados ecológicos. Rio de Janeiro: Interciência, 2000. 114p.

23-Rohlf FJ. Adaptative hierarquical clustering schemes. Systematic Zoology. 1970, 19(1):58-82.

24-Gotelli NJ, Ellison AM. Princípios de estatística em ecologia. 2nd ed. Porto Alegre: Artmed; 2011. p.447-448.

25-Oksanen J et al. Community Ecology Package. 2013.

26-R CORE TEAM. R: A language and environment for statistical computing. R Foundation for Statistical Computing. Vienna, Austria. URL:http://www.Rproject.org/. 2012.

27-Andrade EHA, Zoghbi MGB, Santo AS, Maia, JG. Essential Oils of Piper gaudichaudianum Kunth. and P. regnellii (Miq.) C.DC. Resercha note. Journal Essential Oil Reserch. 1998, 10: 465-467.

28-Silva PP, Péres VF, Saffi J. Extração e caracterização do óleo essencial das inflorescências de Piper gaudichaudianum Kunth. Revista.de Iniciação Científica da Ulbra. 2006, 1(1):25-30.

29-Péres VF et al. Chemical composition and cytotoxic, mutagenic and genotoxic activities of the essential oil from Piper gaudichaudianum Kunth leaves. Food and Chemical Toxicologyv. 2009, 47(9):2389-2395.

30-Santos, T. G. Composição química e atividade antimicrobiana dos óleos essenciais de três espécies do gênero Piper e de Baccharis semiserrata DC. [Dissertação de Mestrado em Química]. Blumenau, Brasil: Universidade Regional de Blumenau; 2009. 117p.

31-Maia JGS et al. Constituents of the essential oil of Piper aduncum L. growing wild in the Amazon region. Flavour and Fragrance Journal. 1998; 13:269-272.

32-Almeida RRP, Souto RNP, Silva MHL, Maia JGS. Chemical Variation in Piper aduncum and Biological Properties of Its Dillapiole-Rich Essential Oil. Chemistry \& Biodiversity. 2009, 6:1427-1434.

33-Potzernheim MCL, Bizzo, HR, Silva JP, Vieira RF. Chemical characterization of essential oil constituents of four populations of Piper aduncum L. from Distrito Federal, Brazil. Biochemical Systematics and Ecology. 2012, 42:25-31.

34-Telascrea M, Araújo CC, Marques MOM, Facanali R, Moraes PLR, Cavalheiro AJ. Essential oil from leaves of Cryptocarya mandioccana Meisner (Lauraceae): Composition and intraspecific chemical variability. Biochemical Systematics and Ecology. 2007; 35:222-232.

35-Duarte AR, Santos SC, Seraphin JC, Ferri PH. Environmental Influence on Phenols and Essential Oils of Myrciaria cauliflora Leaves. Journal Brazilian Chemical Society. 2010, 21(9):1672-1680.

36-Duarte AR, Naves RR, Santos SC, Seraphin JC, Ferri PH. Genetic and Environmental Influence on Essential Oil Composition of Eugenia dysenterica. Journal Brazilian Chemical Society. 2010, 21(8):1459-1467.

37-Ložienè K, Venskutonis PR. Influence of environmental and genetic factors on the stability of essential oil composition of Thymus pulegioides. Biochemical Systematics and Ecology. 2005, 33:517-525.

38-Dixon RA, Achnine L, Kota P, Liu CJ, Srinivasa Reddy MS, Wang L. The phenylpropanoid pathway and plant defence - a genomics perspective. Molecular Plant Pathology. 2002, 3(5): 371-390.

39-Clemes SM. Efeito da sazonalidade e herbivoria sobre a produção de metabólitos secundários voláteis em Piper mikanianum (Kunth) Steudel. [Monografia do curso de Ciências Biológicas]. Blumenau, Brasil: Universidade Regional de Blumenau, 2009.

40-Bastos CN, Albuquerque PSB. Efeito do óleo de Piper aduncum no controle em póscolheita de Colletotricum musae em banana. Fitopatologia Brasileira. 2004, 29(5): 555557

41-Fazolin M, Estrela JLV, Catani V, Lima MS, Alécio MR. Toxicidade do Óleo de Piper aduncum L. a Adultos de Cerotoma tingomarianus Bechyné (Coleoptera: Chrysomelidae). Neotropical Entomology. 2005, 34(3):485-489. 
42-Silva WC, Ribeiro JD'A, Souza HEM, Corrêa RS. Atividade inseticida de Piper aduncum L. (Piperaceae) sobre Aetalion sp. (Hemiptera: Aetalionidae), praga de importância econômica no Amazonas. Acta Amazonica. 2007, 37(2):293-298.

43-Vizcaíno-Páez S, Pineda R, García C, Gil J, Durango D. Metabolism and antifungal activity of safrole, dillapiole, and derivaties against Botryodiplodia theobromae and Colletotrichum acutatum. Boletín Latinoamericano y del Caribe de Plantas Medicinales y Aromáticas. 2015, 15(1):1-17.

44-Albiero, ALM, Souza LA, Mourão KSM, Almeida OJG, Lopes WAL. Morfo-anatomia do caule e da folha de Piper gaudichaudianum Kuntze (Piperaceae). Acta Farmacêutica Bonaerense Jornais Científicos. 2005, 24(4):550-554.

45-Randrianalijaona JA et al. Seasonal and chemotype influences on the chemical composition of Lantana camara L. essential oils from Madagascar. Analytica Chimica Acta. 2005, 545:46-52.

46-Stefanello MEA, Cervi AC, Wisniewski Jr. A, Simionatto EL. Composição e variação sazonal do óleo essencial de Myrcia obtecta (O. Berg) Kiaersk. var. obtecta, Myrtaceae. Revista Brasileira de Farmacognosia. 2010, 20(1):82-86.

47-Dudareva N, Pichersky E, Gershenzon, J. Biochemistry of Plant Volatiles. Plant Physiology. 2004, 135:1893-1902.

48-Cseke LJ, Kaufman PB, Kirakosyan A. The biology of essential oils in the pollination of flowers. Natural Product Communications. 2007, 2(12): 1317-1336

49-Mikich SB, Bianconi, GV, Maia BHLNS, Teixeira, SD. Attraction of the fruit-eating bat Carollia perspicillata to Piper gaudichaudianum essential oil. Journal of Chemical Ecology. 2003, 29(10):2379-2383.

50-48.Baydar H, Sağdiç, O, Özhan G, Karadoğan T. Antibacterial activity and composition of essential oils from Origanum, Thymbra and Satureja species with commercial importance in Turkey. Food Control. 2004, 5:169-172.

51-Gobbo-Neto L, Lopes NP. Plantas medicinais: fatores de influência no conteúdo de metabólitos secundários. Química Nova. 2007, 30(2): 374-381.

52-Figueiredo AC, Barroso JG, Pedro LG, Scheffer JJC. Factors affecting secondary metabolite production in plants: volatile components and essential oils. Flavour and Fragrance Journal. 2008, 23: 213-226. 